\title{
ANG Gene
}

National Cancer Institute

\section{Source}

National Cancer Institute. ANG Gene. NCI Thesaurus. Code C26619.

This gene plays a role in the vascularization of both normal and malignant tissues. 